\title{
Measuring Farmers Risk Aversion in Facing Climate Change in Bengawan Solo Watershed
}

\author{
Umayah, Suryanto \\ Faculty of Economics and Business, Universitas Sebelas Maret, Surakarta \\ Corresponding Author: suryanto_feb@staff.uns.ac.id
}

Received: March 2020 | Revised: June 2020 | Accepted: July 2020

\begin{abstract}
This research aims to understand the effect of risk aversion on the farmers' willingness to pay (WTP) to mitigate on climate change and identify the relationship between climate change and agriculture sectors' growth at Bengawan Solo Sub-Watershed in Upper Area. We use primary data obtained through interviews with 104 respondents, who are farmers from Sribit Village in Sragen Regency. The sampling techniques are purposive non-probability sampling. The data analysis using contingent valuation methods (CVM) and Multiple Linear Log Regression. Meanwhile, the secondary data obtained from The Central Bureau of Statistics (BPS), World Bank, and Germanwatch is collected to identify the effect of climate change on the agricultural sector. This research result shows that risk aversion does not affect farmers' WTP to do adaptation. The variable of land area, education, and input cost affect significantly (5\%), while working experience also affect to WTP at $10 \%$ significance level. The implication of low-risk aversion implies farmers not aware of climate change. Risk reduction efforts will not be a priority for farmers because the advantages to adaptation is not worthy. The relationship between production levels and negative climate change scores confirms that climate change can reduce farmer production.
\end{abstract}

Keywords: Impact of climate change, risk aversion, WTP, agricultural sector.

JEL Classification:

How to Cite: Suryanto, Umayah. (2020). Measuring Farmers Risk Aversioon in Facing Climate Change in Bengawan Solo Watershed. Jurnal Ekonomi Pembangunan: Kajian Masalah Ekonomi dan Pembangunan, 20(2). 91-100. doi:https://doi.org/10.23917/jep.v21i2.7958

DOI: https://doi.org/10.23917/jep.v21i2.7958

\section{Introduction}

Climate change that causing a change in rainfall pattern, length of the rainy season, shift at the beginning of the rainy season, and increase in extreme climate incident (flood and drought) has a serious impact on agricultural sector Surmaini, Runtunuwu, \& Las (2011) increase in frequency of extreme climate events, and rise in temperatures and sea level were serious impacts of climate change faced by Indonesia. Agriculture is most vulnerable sector to impacts of climate change. At the global level, agricultural sector contributes about $14 \%$ of total emissions, while at the national level agricultural sector contributes 12\% (51.20 million tons $\mathrm{CO} 2$ e. According to Agricultural Research and Development Agency (Pertanian, 2011) the effect of climate change such as flood, causing agricultural land to experience crop failure. Increase in flood intensity will affect production indirectly due to pests and plant diseases attack increase. 
Avalaible online at http://journals.ums.ac.id, Permalink/DOI: 10.23917/jep.v21i2.7958

Jurnal Ekonomi Pembangunan: Kajian Masalah Ekonomi dan Pembangunan, 21 (2), 2020, 91-100

Table 1. The Wetland Area that prone to flood/inundation in Java Island

\begin{tabular}{lccccc}
\hline \multicolumn{1}{c}{ Province } & $\begin{array}{c}\text { Highly Prone } \\
\text { (ha) }\end{array}$ & Prone (ha) & $\begin{array}{c}\text { Less } \\
\text { Prone (ha) }\end{array}$ & $\begin{array}{c}\text { Not Prone } \\
\text { (ha) }\end{array}$ & Total (ha) \\
\hline West Java & 27,654 & 205,304 & 324,734 & 409,984 & 967,676 \\
Banten & 7,509 & 53,472 & 89,291 & 42,259 & 192,531 \\
Central Java & 49,569 & 503,803 & 188,688 & 303,346 & $1,045,406$ \\
Special Region of Yogyakarta & - & 15,301 & 34,459 & 13,622 & 63,382 \\
East Java & 105,544 & 306,337 & 533,447 & 359,630 & $1,304,958$ \\
Total & 162,622 & $1,084,217$ & $1,170,619$ & $1,128,841$ & $3,573,953$ \\
Percentage & 4.5 & 30.3 & 32.7 & 32.5 & 100.0 \\
\hline
\end{tabular}

Source: Boer et al. (2009)

Table 2. Land Usage on Upper Region of Bengawan Solo Sub-Watershed Area in 2016 (Ha)

\begin{tabular}{lccc}
\hline Regency/Municipality & Paddy Field & Not Paddy Field & Total \\
\hline Klaten & 33.398 & 32.158 & 65.556 \\
Sukoharjo & 21.256 & 25.410 & 46.666 \\
Karanganyar & 22.133 & 55.087 & 77.220 \\
Sragen & 39.763 & 54.886 & 94.649 \\
Surakarta City & 103 & 4.300 & 4.403 \\
\hline
\end{tabular}

Source: Central Java BPS (2016)

Based on Table 1, the Central Java Province is the second biggest Province after East Java with the vast wetland area that prone to floods/ inundation, floods in wetland area will lead to a decrease in harvest area and a significant decrease of rice production. However, Central Java Province remains to become one of the largest rice suppliers in Indonesia.

Bengawan Solo watershed area is the largest watershed in Java, which extends from the Central Java to East Java. This watershed is divided into three sub watershed upper, middle, and lower sub watershed regions. Bengawan Solo watershed is a source of water to fulfill the needs of the surrounding community such as domestic activity, industrial raw water and drinking water, irrigation, and others. During the dry season, the watershed area often experiences a drought, while in rainy season several area experiencing a flood disaster. The areas prone to flooding are Wonogiri, Sukoharjo, Karanganyar, Klaten, Surakarta, and Sragen.

Based on Table 2, the highest paddy field land usage is located in Sragen Regency with
39,763 hectares, while the smallest usage is in Surakarta city with 103 hectares of paddy field. Paddy field usage, either large or narrow will have flooding risk and threatens people' life, especially farmers who reside in Bengawan Solo sub-watershed area. The risk depends on the vulnerability and capacity of the community. The more vulnerable the community is, the higher the probability to be affected by the negative impact of climate change.

Many studies related to the effect of climate change to agricultural productivity have been conducted by (Runtunuwu \& Syahbuddin, 2007); Murad, et al. (2010), Ayinde, Muchie, \& Olatunji, (2011); Iglesias, el al. (2011); and Ruminta (2016), and the newest Mo, et al. (2017). Extreme climate change and its impact will significantly affect the agricultural sector. This is due to climate change causing a shift in the pattern and quantity of rainfall that leads to shifting at the beginning of the planting season and planting period. Rainfall pattern will affect planting period and planting season, planting pattern, land degradation, plants damage and its productivity, planting area and 
harvest area, as well as damage to biodiversity, especially food crops. In general, food crops and horticulture is a seasonal plant that sensitive to stress such as the excess and deficiency of water (Runtunuwu and Syahbuddin, 2007).

Murad et al. (2010) conduct research to understand and analyze the relationship between agricultural growth and climate change score; to determine and analyze the relationship between per capita $\mathrm{CO} 2$ emissions and agricultural production indices. The result shows that there are three important observations for Malaysia: the relationship between agricultural sector growth with climate change score is negative but is not significant ( $p>0.1$ ); the relationship between $\mathrm{CO} 2$ emission per capita and production indices is direct and significant $(p<0.01)$; and the relationship between agricultural production per capita indices and $\mathrm{CO} 2$ emission per capita is positive and significant $(\mathrm{p}<0.01)$.

The impact of climate change also conducted in Nigeria Africa. The researcher found that there is a variability in rainfall and temperature in Nigeria, the increase of air temperature has an effect on agricultural productivity drop. High temperature affects the nutrients contained in the soil thus creating a negative effect on agriculture Meanwhile rainfall has a positive effect on agricultural productivity in Nigeria because it does not cause floods, unlike the preceding year when high rainfall result in crop failure and decrease the farmers' productivity (Muchie and Olatunji, 2011).

In Indonesia, a study on the effect of climate change focused on the decrease of paddy production in Bandung Municipality, West Java by Ruminta (2016). He showed that the climate change effect in Bandung Municipality is already felt by farmers, which indicated by the shift in planting season and harvest time, decrease in planting and harvest area, as well as change in productivity and paddy productivity in the rainfall areas and half irrigated rice field. However, there are many adaptation attempt to address the risk of paddy production drop due to climate change effect such as using superior varieties paddy, which is resistant to drought/flooding and has early maturity, and increasing the technique and intensification of rice cultivation.

The recent research conducted by Mo, et al. (2017) in North China. They stated that impact of climate change in north China has decreased the supply of water and potentially triggered to dry season. Many researchers have agreed that the impact of climate change are negative to their livelihood. Rusminah \& Gravitiani, (2012) conducted research to identify and map the flood-prone areas in Surakarta ex-residency and analyze the mitigation for flood as well. The result shows that income, age, education, and the number of the family member has a significant effect on willingness to pay and perform a flood mitigation. Further, they found that respondents' (farmers) ability to pay (WTP) for flood mitigation in average is between 250,000 and 500,000 IDR, while they will experience loss for around $50 \%$ from normal production output when there is a flood in Bengawan Solo watershed area. Similarly with result of Deressa, Hassan, \& Ringle (2011), social economy factors, such as: age and education have influence to the adaptation option in agriculture.

To reduce the negative impact of climate change can be developed by two strategies: adaptation and mitigation. Coping the risk of climate change by adaptation is important to measure risk aversion of individual i.e farmers. Adaptation in agricultural systems has many various option, Fosu-Mensah, Vlek, \& MacCarthy (2012) concluded that adaptation requires a multidisciplinary approach and is influenced by other variables. Furthermore, they stated that if farmers do not adapt it means that farmers do not want to adapt or are not aware of the risks (Iglesias et al., 2011). Farmers also will do adaptation when they estimate that the potential loss is higher than cost of adaptation (Dang,et al., 2014).

Risk aversion is a decision-making process made by every individual on a risk based on the degree of yield guarantee preference within a set of probability. Higher preference on an assurance, the higher risk aversion or lower tolerance toward 
risk. Several studies (Fahad \& Jing, 2018; Rulleau, Rey-Valette, \& Hérivaux, 2015) stated differences in the results of the effect of risk aversion on WTP adaptation to research conducted by Suryanto \& Kuncoro (2012). Nevertheless, they agreed that willingness to do adaptation was influenced by risk aversion. Therefore, identification and investigation of risk aversion are interesting to study as a basis for carrying out policies. According to Ali \& Erenstein (2017), there is a tendency for differences in farmers' attitude or behavior (reluctant or not) to bear the risk. Riddel, (2013) stated that the farmers who are risk-averse will be allocated different input compared to risk taker or risk-neutral farmer.

The hypothesis that can be proposed based on previous research studies is that farmers' risk aversion will have a positive effect on WTP. Length period as a farmer is a proxy for experience farming will also have a positive effect on WTP. Farmers increasingly understand and aware toward issue of climate change is a real problem that threatens their production. Input cost variables and square of own land area also be predicted have a positive effect on WTP, increasing of input cost that they spend for cost production and higher square of own land area made them do not want to bear more losses. The variable climate change adaptation tries to show that farmers who adapt to climate change will have a positive influence on WTP.

Based on the background, this research aims to understand the effect of risk aversion on farmers willingness to pay (WTP) and to know the effect of climate change on the agricultural production performance using a proxy of the agriculture sector's growth, climate change score, and $\mathrm{CO} 2$ emission at the upper region of Bengawan Solo sub-watershed area.

\section{Research Methodology}

\subsection{Research Design}

This research uses the quantitative method where the value of each change in a variable can be expressed in numbers. In analyzing economics valuation and examining the effect of risk aversion on farmers' WTP to perform mitigation, we use survey design using the questionnaire as primary data collection tools from the research sample. This research is included in crosssectional category; research that collects data through questionnaires at one time only.

We use Nonprobability Sampling method, a sampling technique that does not provide the same opportunity or possibility to every member of the population to be selected as a research sample (Sugiyono, 2012). The analysis unit in this research is individual; all farmers' group in Sribit Village (Newo, Semboan, and Tambak), Sidoharjo District, Sragen Regency. While, the secondary data such as climate change score, $\mathrm{CO} 2$ emission score, and paddy production are obtained from Germanwatch and Central Bureau of Statistics (BPS).

\subsection{Population and Sample}

The population of this study is the farmers who live in the hazardous region (flooded potentially) especially in Sribit Village. Based on SIG analysis has known that the number of the farmers is 141 households. The method used to determine the sample size is Slovin formula as follows:

$$
n=\frac{\mathrm{N}}{1+N e^{2}}
$$

Where: $\mathrm{n}$ is the number of sample as respondent; $\mathrm{N}$ is the number of population of farmers who suffered potentially caused flood. Level of tolerable error limits is $5 \%$ and the number of farmers selected as research sample we use Slovin formula (Sugiyono, 2008). Therefore, there are 104 samples taken from Sribit Village (Newo, Semboan, and Tambak Sub Village). Sampling is done using purposive non-probability sampling method, that is only involve farmers who active in flood-prone rice fields in the selected villages.

\subsection{Data Analysis Model}

To understand the effect of Risk Aversion on farmers' WTP and mitigation, the primary data analysis using Contingent Valuation Methods 
Jurnal Ekonomi Pembangunan: Kajian Masalah Ekonomi dan Pembangunan, 21 (2), 2020, 91-100

(CVM) and multiple linear regression analysis using log linear model. Model log linear have some advantages than model linear, model log linear can be interpreted as an elasticity. In this model, log of WTP as dependent variable and log input cost, log land area, education, experience, and climate change as independent variables. Meanwhile, to understand the relationship of climate change score, $\mathrm{CO}_{2}$ emission, and paddy production we use correlation analysis using SPSS.

According to Gujarati (2003), multiple linear regression is conducted to know the effect of dependent variable on independent variable. The analysis technique used is log linear model.

Formula:

$\mathrm{WTP}=B_{0}+\beta_{1} X_{1}+\beta_{2} \mathrm{X}_{2}+\beta_{3} \operatorname{Ln} X_{3}+\beta_{4} \operatorname{Ln} X_{4}+$ $B_{5} X_{5}+B_{6} \mathrm{X}_{6}+\mathrm{e}$

WTP is Willingness to pay to do adaptation in order to decrease risk of climate change. The value of willingness be measured as how much they spend to avoid risk exlude cost of production; $\mathrm{X}_{2}$ is length of time for experience become a farmer (year); $\mathrm{X}_{3}$ is Variable cost that farmers spent for every planting period ; $\mathrm{X}_{4}$ is land area owned by farmers (square meters); $\mathrm{X}_{5}$ is dummy variable to classify a farmer who do adaptation and farmer who do nothing; $\mathrm{X}_{6}$ is risk aversion variable which shows the degree of rejection of the risk of flood or drought

\section{Result and Discussion}

\subsection{Results}

Multiple linear regression analysis aims to determine the effect of land area, input cost, experience, education, risk aversion, and climate change adaptation on willingness to pay (WTP) in Sribit village, Sidoharjo district, Sragen Regency. The model used is log linear model on SPSS software. The regression results can be seen in Table 3.

Based on table 3, the formula shows the relationship between education, land area, risk aversion, input cost, climate change adaptation, and experience, and willingness to pay (WTP) in the agricultural area that is vulnerable to floods. The data analyzed has passed the classical assumption test. The VIF value in multicollinearity test shows that education, experience, input cost, land area, climate change adaptation, and risk aversion $\leq 10$, we can conclude that there is no multicollinearity in the independent variables. The significance value of heteroskedasticity test for each independent variable is larger than 0.05 , thus we can conclude that regression model does not contain heteroskedasticity, therefore the model fulfills the classical assumption for multiple linear regression testing.

Table 3. Result of Multiple Linear Regression Analysis

\begin{tabular}{lccc}
\hline \multicolumn{1}{c}{ Variable } & Coefficient & t-statistic & Sig \\
\hline (Constant) & 5.212 & 57.607 & .000 \\
Education & .020 & 2.683 & $.009^{*}$ \\
Experience & -.006 & -1.724 & $.088^{* *}$ \\
Input Cost & $2.383 \mathrm{E}-008$ & 3.007 & $.003^{*}$ \\
Land Area & $6.118 \mathrm{E}-005$ & 7.934 & $.000^{*}$ \\
Climate Change & .036 & .773 & .442 \\
Risk Aversion & .037 & 1.194 & .235 \\
\hline R square & $\mathbf{0 . 8 0 0}$ & & \\
Adjusted R-Squared & $\mathbf{0 . 7 8 7}$ & & \\
\hline
\end{tabular}

Source: processed primary data (2018)

* significant at 5\% level

$* *$ significant at $10 \%$ level 
The regression formula obtained is as follows: Ln WTP=5.212+0.009 $\mathrm{X}_{1}-0.006 \mathrm{X}_{2}+2,383 \mathrm{E}-008 \mathrm{X}_{3}$ (2.683) (-1.724) (3.007) $+6.118 \mathrm{E}-005 \mathrm{X}_{4}+0.036 \mathrm{X}_{5}+0.037 \mathrm{X}_{6}$ $(7.943) \quad(0.773) \quad(1.194)$

In the statistical testing, $\mathrm{F}$ test shows that land area, input cost, education, farming experience, risk aversion, and climate change adaptation simultaneously affect willingness to pay (WTP) in Sribit village, Sidoharjo District, Sragen Regency. The t-test shows that education, input cost, and land area significantly affect willingness to pay (WTP) Sribit village, Sidoharjo sub-district, Sragen regency at a significance level of $5 \%$, while farming experience, risk aversion, and climate change adaptation has no significant effect on willingness to pay. Some previous results revealed that variables related to climate change is not significant enough influence to WTP. awareness of farmers to climate change have to increase (Gebrehiwot \& Van Der Veen, 2013), (Khanal, Wilson, Hoang, \& Lee, 2018), and (Ali \& Erenstein, 2017).

The coefficient of determination $\left(\mathrm{R}^{2}\right)$ is 0.80 which means $80 \%$ of variations in the dependent variable, in this case, the willingness to pay (WTP) can be explained by independent variables that consist of land area, input cost, education, farming experience, risk aversion, and climate change adaptation. The rest $20 \%$ is explained by other variables outside the model.

\subsection{Economic Interpretation of Results}

The coefficient regression for education is 0.020 with a significance value of 0.009 . Education has a significant effect on WTP in performing mitigation. The higher education level is expected to make a farmer be more rational. When the length of education increase 1 year will increase WTP $0,009 \%$. This result is consistent with Ghazanfar, Qi-wen, Abdullah, Ahmad, \& Lateef, (2015); Fan \& Davlasheridze, (2016), and Fahad \& Jing (2018).

The coefficient regression for experience is -0.006 with a significance level of 0.088 , therefore experience has a negative and significant effect on willingness to pay in performing mitigation. Actually the longer the experience in farming is not influenced to the awareness in mitigation and willingness to pay (WTP). When the experience of the farmer that measured by length as a farmer increased one year will affect decreasing to WTP 0,088 percent. This result is a difference with Wachinger, et al. (2013), they stated there was a positive correlation between longer experience to WTP mitigation.

The coefficient regression for input cost is 2.383E-008 with the significance level of 0.003 , therefore input cost has a significant effect on willingness to pay in performing mitigation. The high input cost is expected to increase the willingness to pay (WTP). When the farmer raised their expenditure to cost of input 1000 IDR will increase three percent of WTP mitigation. Gravitiani, Suryanto, \& Antriyandari, (2016) explained that higher input costs will affect WTP mitigation because the farmer has a higher risk.

The coefficient regression for the land area is $6.118 \mathrm{E}-005$ with a significance value of 0.000 , therefore land area has a significant effect on willingness to pay in performing mitigation. The larger the land they owned, the farmer will tend to increase their level of willingness to pay. When there is an increasing one hectare in the land area will increase the willingness to pay (WTP). Ullah, Shivakoti, \& Ali, (2015) stated that farmers who managed larger farms were primarily concerned with production risks. Consequently, they will allocate their resources higher than a farmer who managed smaller farms.

The coefficient of regression of climate change adaptation is 0.036 with a significance level of 0.442 , therefore this variable has no significant effect on willingness to pay in performing adaptation. This result is rejected the finding from Hidayati \& Suryanto (2015), farmers who live in vulnerable areas have to increase their adaptation strategy to reduce the loss caused by climate change. Farmers can change their farming pattern or shifting cropping period to 
Jurnal Ekonomi Pembangunan: Kajian Masalah Ekonomi dan Pembangunan, 21 (2), 2020, 91-100

adjust with the start of the rainy season to reduce the risk of crop failure. Regarding this issue, the result of an interview on 104 respondents shows that $85.58 \%$ choose to shift their cropping period based on the rainy season to reduce the risk of crop failure. Although this result is not accordance with Hidayati \& Suryanto (2015), this finding has adding explanation of (Iglesias et al., 2011)

The coefficient of regression for risk aversion is 0.037 with significance value fo 0.235 , therefore risk aversion has no significant effect on willingness to pay in performing mitigation. Regarding this issue, a similar result has been found by Suryanto and Kuncoro (2012), but contradictory with result some results such as Rulleau et al., (2015) and Fahad \& Jing (2018). Even, Ozdemir \& Kruse (2000) based on expected utility theory, individuals who live in the areas that are vulnerable to a natural disaster will try to maximize the utility by mitigating the threatening disasters.

The answer why the risk aversion does not affect to willingness to pay could be explained based on result of interview to respondents. The result of the interview with 104 respondents shows that the highest risk category is risk neutral with $52.88 \%$. We can conclude that the majority of farmers in Sribit village has risk neutral or neutral to risk. This shows that most people in the areas that vulnerable to flood has very low willingness to pay to reduce the risk of crop failure caused by a flood. The willingness to pay is even lower than the total loss that will be experienced if a flood occurs. The majority of farmers in Sribit village willing to pay only as much as planting cost for the next plating if there is a risk of crop failure caused by a flood. This might be caused by several socio-economic factors that affect their willingness to pay.

Finally, WTP to adapt the climate change risk can be explained by independent variables that consist of land area, input cost, education, farming experience, risk aversion, and climate change adaptation. The rest $20 \%$ is explained by other variables outside the model.

\subsection{The Correlation between Climate Change and Agricultural Sector}

This study employs correlation analysis to find the relationship among paddy production, CO2 emission, and climate score (CRI). Based on the processed data, the following is the result of correlation analysis between agricultural production and the increase in $\mathrm{CO} 2$ emission:

Table 4. Result of Correlation Analysis on Paddy Production and $\mathrm{CO}_{2}$ Emission

\begin{tabular}{lcc}
\hline \multicolumn{1}{c}{ Variable } & Pearson Correlation & Sig \\
\hline Paddy production & -0.621 & 0.000 \\
$\mathrm{CO}_{2}$ Emission & -0.621 & 0.000 \\
\hline
\end{tabular}

Source: Processed secondary data (2018)

Based on Table 4, the correlation coefficient is -0.621 . The negative value means that there is a negative relationship between paddy production and $\mathrm{CO} 2$ emission. The 0.621 score means that there is a strong correlation between paddy production and $\mathrm{CO} 2$ emission, therefore we can conclude that there is a strong and negative correlation between paddy production and $\mathrm{CO} 2$ emission. The higher the $\mathrm{CO} 2$ emission, the lower is paddy production, and vice versa. Following is the result of analysis on the relationship between climate change score (CRI) and the growth of the agricultural sector (agricultural production):

Table 5. Result of Correlation Analysis on Climate Change and Paddy Production

\begin{tabular}{lcc}
\hline \multicolumn{1}{c}{ Variable } & Correlation & Sig \\
\hline Paddy production & -0.558 & 0.00 \\
$\mathrm{CO}_{2}$ Emission & -0.558 & 0.000 \\
\hline
\end{tabular}

Source: Processed secondary data (2018)

Based on Table 5, the correlation coefficient is -0.558 . The negative value indicates a negative relationship between climate change and paddy production. The 0.558 value means that there is a medium relationship between climate change and paddy production, therefore we conclude that 
there is a negative correlation between climate change and paddy production. The higher the climate change or CRI score, the lower is paddy production, and the contrary; the lower is the CRI score, the higher is the paddy production.

\section{Conclusion}

The risk aversion variable and climate change adaptation do not have an effect on willingness to pay (WTP). According to the interviews, farmers in Sribit Village are mostly risked neutral or risk-neutral, as evidenced by the interviews with $52.88 \%$ answering risk neutral. Further, the majority of farmers in Sribit Village can only afford to buy seeds if crop failures occur. Educational variables, land area, experience, and input costs influence the willingness to pay (WTP) positively. The results of the analysis show that the correlation between rice production and climate score (CRI) and CO2 emissions in the Bengawan Solo Subdistrict of the Upper region especially the Klaten, Sragen, Karanganyar, Sukoharjo, and Surakarta regions are negatively correlated. The higher the level of climate change or CRI score and $\mathrm{CO} 2$ emissions, the lower the rice production.

\section{Implication}

Farmers who live in flood-prone areas, especially in the study sample areas, must raise awareness of the risk of crop failure. Increased awareness will increase farmers' adaptive ability to climate change. There needs to be socialization to farmers about the risk of losses due to flooding, so it is expected that farmer behavior will change from risk neutral to risk aversion. The local government should also understand that adaptation measure is not individual problem but social problems and multi aspects. Iglesias et al., (2011) explained that to increase adaptation should involve the other issues of risk factors, such as climate variability and market risk, and sustainability development scheme in 2030 . Government can increase the efficiency of markets by provide the facility to help farmers do adaptation such as: providing weather forecast information and repairing drainage channels.

\section{Referrences}

Ali, A., \& Erenstein, O. (2017). Assessing farmer use of climate change adaptation practices and impacts on food security and poverty in Pakistan. Climate Risk Management. https://doi.org/10.1016/j.crm.2016.12.001

Ayinde, O. E., Muchie, M., \& Olatunji, G. B. (2017). Effect of Climate Change on Agricultural Productivity in Nigeria: A Cointegration Model Approach. Journal of Human Ecology. https://doi.org/10.1080/09 709274.2011.11906406

Dang, H. Le, Li, E., Nuberg, I., \& Bruwer, J. (2014). Understanding farmers' adaptation intention to climate change: A structural equation modelling study in the Mekong Delta, Vietnam. Environmental Science and Policy. https://doi.org/10.1016/j. envsci.2014.04.002

Deressa, T. T., Hassan, R. M., \& Ringler, C. (2011). Perception of and adaptation to climate change by farmers in the Nile basin of Ethiopia. Journal of Agricultural Science. https://doi.org/10.1017/ S0021859610000687

Fahad, S., \& Jing, W. (2018). Evaluation of Pakistani farmers' willingness to pay for crop insurance using contingent valuation method: The case of Khyber Pakhtunkhwa province. Land Use Policy, 72(December), 570-577. https://doi.org/10.1016/j. landusepol.2017.12.024

Fan, Q., \& Davlasheridze, M. (2016). Flood Risk, Flood Mitigation, and Location Choice: Evaluating the National Flood Insurance Program's Community Rating System. Risk Analysis. https://doi.org/10.1111/risa.12505

Fosu-Mensah, B. Y., Vlek, P. L. G., \& MacCarthy, D. S. (2012). Farmers' perception and adaptation to climate change: A case study of Sekyedumase district in Ghana. Environment, Development and Sustainability. https://doi.org/10.1007/ s10668-012-9339-7 
Jurnal Ekonomi Pembangunan: Kajian Masalah Ekonomi dan Pembangunan, 21 (2), 2020, 91-100

Gebrehiwot, T., \& Van Der Veen, A. (2013). Farm level adaptation to climate change: The case of farmer's in the ethiopian highlands. Environmental Management. https://doi. org/10.1007/s00267-013-0039-3

Ghazanfar, S., Qi-wen, Z., Abdullah, M., Ahmad, Z., \& Lateef, M. (2015). Farmers' Perception and Awareness and Factors Affecting Awareness of Farmers Regarding Crop Insurance as a Risk Coping Mechanism Evidence from Pakistan. Journal of Northeast Agricultural University (English Edition), 22(1), 76-82. https://doi. org/10.1016/s1006-8104(15)30010-6

Gravitiani, E., Suryanto, \& Antriyandari, E. (2016). Willingness to Pay for Climate Change Mitigation: Application on Big Cities in Central Java, Indonesia. Procedia - Social and Behavioral Sciences. https:// doi.org/10.1016/j.sbspro.2016.06.095

Hidayati, I. N., \& Suryanto. (2015). Pengaruh Perubahan Iklim Terhadap Produksi Pertanian Dan Strategi Adaptasi Pada Lahan Rawan Kekeringan. Jurnal Ekonomi \& Studi Pembangunan. https:// doi.org/10.18196/jesp.16.1.1217

Iglesias, A., Quiroga, S., Diz, A., \& Garrote, L. (2011). Adapting agriculture to climate change. Economia Agraria y Recursos Naturales.

Khanal, U., Wilson, C., Hoang, V. N., \& Lee, B. (2018). Farmers' Adaptation to Climate Change, Its Determinants and Impacts on Rice Yield in Nepal. Ecological Economics, 144. https://doi.org/10.1016/j. ecolecon.2017.08.006

Mo, X. G., Hu, S., Lin, Z. H., Liu, S. X., \& Xia, J. (2017). Impacts of climate change on agricultural water resources and adaptation on the North China Plain. Advances in Climate Change Research, 8(2), 93-98. https://doi.org/10.1016/j.accre.2017.05.007

Murad, W., Islam Molla, R., Bin Mokhtar,
M., \& Raquib, A. (2010). Climate change and agricultural growth: An examination of the link in Malaysia. International Journal of Climate Change Strategies and Management. https://doi. org/10.1108/17568691011089927

Ozdemir, O., \& Kruse, J. B. (2000). Relationship Between Risk Perception and Willingnessto-Pay for Low Probability, High Consequence Risk: A Survey Method. Risk Analysis.

Pertanian, K. PERATURAN MENTERI PERTANIAN NOMOR: 44/Permentan/ OT.140/8/2011 TENTANG PEDOMAN UMUM PERENCANAAN PENELITIAN DAN PENGEMBANGAN PERTANIAN. , (2011).

Riddel, M. (2013). How Do Long-Shot Outcomes Affect Preferences for Climate-Change Mitigation? Southern Economic Journal. https://doi.org/10.4284/0038-4038-2011.231

Rulleau, B., Rey-Valette, H., \& Hérivaux, C. (2015). Valuing welfare impacts of climate change in coastal areas: a French case study. Journal of Environmental Planning and Management. https://doi.org/10.1080/0 9640568.2013.862492

RUNTUNUWU, E., \& SYAHBUDDIN, H. (2007). Perubahan Pola Curah Hujan dan Dampaknya Terhadap Periode Masa Tanam. Jurnal Tanah Dan Iklim. Retrieved from http://ejurnal.litbang.pertanian.go.id/ index.php/jti/.

Rusminah, R., \& Gravitiani, E. (2012). Kesediaan Membayar Mitigasi Banjir Dengan Pendekatan Contingent Valuation Method. Jurnal Ekonomi \& Studi Pembangunan, 13(1), 12-23. https://doi.org/10.18196/ JESP.13.1.1252

Surmaini, E., Runtunuwu, E., \& Las, I. (2011). Efforts of Agricultural Sector in Dealing with Climate Change. Jurnal Litbang Pertanian. 
Avalaible online at http://journals.ums.ac.id, Permalink/DOI: 10.23917/jep.v21i2.7958

Jurnal Ekonomi Pembangunan: Kajian Masalah Ekonomi dan Pembangunan, 21 (2), 2020, 91-100

Suryanto, \& Kuncoro, M. (2012). RISK PERCEPTION AND ECONOMIC VALUE OF DISASTER MITIGATION. South East Asian Journal of Management. https://doi. org/10.21002/seam.v6i2.1319

Ullah, R., Shivakoti, G. P., \& Ali, G. (2015). Factors effecting farmers' risk attitude and risk perceptions: THE case of Khyber Pakhtunkhwa, Pakistan. International Journal of Disaster Risk Reduction. https:// doi.org/10.1016/j.ijdrr.2015.05.005

Wachinger, G., Renn, O., Begg, C., \& Kuhlicke, C. (2013). The risk perception paradoximplications for governance and communication of natural hazards. Risk Analysis. $\quad$ https://doi.org/10.1111/j.15396924.2012.01942.x 